\title{
2 The world at the ultimate crossroads
}

\section{Climate change, environmental impacts, population and natural resources sufficiency in the long perspective with integrated models}

\author{
Harald Ulrik Sverdrup, Ullrich Lorenz, \\ and Anna Hulda Olafsdottir
}

\section{Introduction and background}

In the last decade, many have come to the conclusion that the world has reached and transgressed the confines of the planetary capacities and boundaries, resulting in the realization that humanity may one day become limited by declining availability of food, energy and natural resources (Bardi 2013; Rockström et al. 2009, 2017; Heinberg 2011; Monbiot 2015; Sverdrup and Ragnarsdottir 2014). In addition, it has become clear that human civilization is creating pollution on such a big scale that the environment of the entire globe is affected in a substantial way.

We have gone to many meetings on sustainability over the past four decades, and in every meeting many researchers hold elaborate and compassionate talks on how everything is linked and connected. And then we all go home, and meet again the year after, and the same thing happens again, many hold elaborate and compassionate talks on how everything is linked and connected. And nothing happens to connect the aspects they talked so much about. No one connects anything for real in their models, nor in their work. They just talk about it. Again and again. One day we decided we would do those connections, for real, not just talk like everyone else seems to be doing, but actually make a model where everything was connected.

\section{Scope and objectives}

\section{The scope and objective of this report}

Each of the challenges may appear alone as to be overpowering. When the gridlock of impending natural resources exhaustion, population growth, energy transitions, continued pollution, increasing climate change, escalating environmental impacts, social challenges, the decay of governance and unstable 
economy, all come together, it is the largest challenge of all times. It truly calls for extraordinary thinking and truly transformative actions. We were not the first to take up the challenge of an all-connecting model. Forrester $(1961,1969$, 1971) and the Meadows team (Meadows et al. 1972, 1974) had been there before. They had laid a solid foundation but met very hard challenges, one being that computers at the time were not really up to the task, as well as suffering large scale political attacks.

\section{The purpose of the WORLD7 model}

The purpose of the WORLD7 model is to assess the overall sustainability of the global civilisation and use the model for policy development in single countries and regions; Germany, Sweden, Europe. In our times, the sustainability of our societies has become challenged from a number of factors:

- Global climate change has been in progress for a long time, and now the effects are becoming visible to the layman and politician alike. The effects have substantial economic and social impacts.

- The global population has grown to levels where crowdedness and high density creates a tougher society with less margin for any type of error. Industrial and urban impacts in all aspects are substantial and global in scale. In times of economic and social stress, more extreme political forces have appeared on the arena in larger numbers than seen before, and many democracies are facing serious challenges.

- A longer period of peace and prosperity have created a growth in global wealth, but a relaxed policy towards wealth redistribution, that have allowed economical differences to grow enough in many regions to increase social tensions.

All of the issues listed above are causally linked in an intricate system, where policy becomes increasingly more difficult to develop and implement. We are in a period which will experience natural resource scarcity on a large scale across all resources, challenging economies and societies. Exhaustion does not necessarily imply that there are no resources available, but they will be harder and harder to get out of the ground, present in lower and lower quality in the materials we lift up, causing more pollution and demanding more work efforts per unit gained.

\section{Methodology}

\section{Model development methodology}

The main tool employed to build the WORLD7 model are the standard methods of system analysis and system dynamics modelling (Forrester 1961, 
1969, 1971; Meadows et al. 1972, 1974, 1992, 2005; Clark and Cole 1975; Roberts et al. 1982; Senge 1990; Bossel 1998; Sterman 2000; Haraldsson and Sverdrup 2005). In 1961, Forrester created the first draft of a system dynamics model of the world's socio-economic system, World1, in response to a challenge by the Club of Rome (Forrester 1961). Forrester refined this to become World2 (Forrester 1969). World2 was published in a book titled World Dynamics (Forrester 1971) attempting to model the global economy. The Club of Rome initiated further work into this issue and Meadows et al. (1972) published the outputs from their World3 model in the book 'Limits to growth'. World models is based on system dynamics have gone through four development phases:

- 1961-1971; World1-World2; Forrester team (1961-1971), MIT; Industrial dynamics, urban dynamics, world dynamics, the first pioneering basic concept for how a World model may be put together. The model was very simplified and aggregated to a high level because of the limitations of the computers available at the time (Forrester 1961, 1969, 1971).

- 1972-2004; World3; The Meadows team (1972-2004), MIT; World dynamics and limits to growth. The model was more elaborate than World2, better parameterised and described in the book 'Dynamics of Growth in a Final World' (Meadows et al. 1972, 1974). The model had significant simplifications because of computational constraints of the computers available at the time.

- 2011-2017; WORLD4-WORLD6; Sverdrup team (2013-2016), University of Lund, Sweden, University of Iceland, and Inland University of Applied Science, Norway. WORLD6 has reality-based market mechanisms and simulates commodity and resource price dynamics internally. WORLD6 handles the global economic and financial development and captures economic cycles of growth, stagnation, and decline. link natural resources, economy, finances, governance, demography, society and social process dynamics (Sverdrup and Ragnarsdottir 2014; Lorenz et al. 2017; Sverdrup et al. 2013, 2014a,b, 2015a,b, 2017). WORLD6 has no software parts from the earlier models.

- 2017-2019; WORLD7 is the new, reorganized version by the Sverdrup team, where it all is coming together in a functioning Integrated Assessment Model (IAM) and is used operationally in European Research projects. A present social and socio-economic modules are under development.

The WORLD7 model differs from the earlier models in most aspects. Several weaknesses in the earlier World1 and World3 models were exploited as points of attack against the older model. It is important to understand that most of the attack on the World3 model and on the Meadows team, did not have much to 


\section{Harald Ulrik Sverdrup et al.}

with science. The majority of the attacks were driven by the defence of political ideology and thus were deeply political in their nature. We can observe that against prejudice and fear of change, logic does not always apply (Nørgaard et al. 2014; Keegan and Laskow-Lahey 2014; Kotterer 2014). Meadows have told me later that he regretted some of those simplifications, but considering the computers he had available, there was not much choice.

1 Natural resources

a World3: All resources were lumped together, (energy, fossil fuels, metals, materials, water), adding them up into one resource index R. This became a major line of attack against the World3 model, and to some degree, this was justified.

b WORLD7: Reserves and resources are distinguished and the Benefit Return On Investment (BeROI, a generalized version of EROI), if a resource required more effort (energy, materials) to extract that it gives benefit, then the extraction stops.

i The resources are treated individually. Energy is divided up into fossil energies; Hydrocarbons oil, gas and coal, uranium and thorium.

ii Technological energy sources like wind and solar electric harvest, which have sustainable energy source but needs metals in short supply.

iii Sustainable energy which uses abundant materials and sustainable sources of energy; hydropower and provided they are grown sustainably; biofuels.

iv Metals and materials are treated individually, from individual resource reserves and resources and traded individually in a world market.

\section{Economics:}

a World3: The model had a very simplified economic model, a simple cash box and total invested capital. When the cash box ran empty, the model crashed the world.

b WORLD7: The model operates with several types of capital, where each stock keeps a part of society running, as well as a stock of liquid capital. Investments are solved with a mix of capital and debt. In times of societal deficits, the government can issue bonds, take up debts or print money. This is an effective way to bridge fluctuations in the economy. It will not resolve structural problems unless the debt is used for structural change. The WORLD7 model accommodates this.

\section{Pollution}

a World3: This was generalised into something called persistent pollution, adding up all kinds of pollution into one index $\mathrm{P}$ for pollution of any kind. The model assumed pollution to limit the birth 
rate and food production, and the model came to a halt when the pollution got high enough.

b WORLD7: Pollution is specified into several types, according to their characteristics and what they affect, it operates with these types:

i $\mathrm{CO}_{2}$ from calcination and carbon fuel combustion and $\mathrm{CH}_{4}$ that leaks from natural gas production and use, they affect the global climate

ii Endocrine disruptors that drive health problems and disrupt immune systems, they affect fertility, health costs and mortality

iii Persistent organic pollution (POP)

iv Antibiotics that when lost in nature cause microbial resistance in addition to regular use, and this drives health costs and mortality

$\mathrm{v}$ SOx, NOx and particulate emissions, that drive acidification and a number of other issues. They affect health costs and mortality

vi Heavy metals that affect the ecology and in the end humans, with effects into health costs and mortality

4 Social aspects:

a World3 avoided all social aspects.

b WORLD7 has:

i Wage distribution in society and gender pay equality

ii Quantitative aspects of wellbeing

iii Rate of illness and mortality, rate of health services, medical treatment and care provision

iv Aspects of Quality of Governance

An important difference from World3 to WORLD7, is that the global economy and the population is not made to crash in the model when the resources become scarce. The system stability is caused by mechanisms of financing deficits in WORLD7, using monetary loans and state bonds to buffer variations in the economic system, as postulated by Keynes et al. (1932) and Keynes (1936). To balance the system, these loans need to be repaid, which can be pushed forward when the economy grows steadily. When the growth declines toward stagnation, it will become more and more difficult to repay the loans if they are too large. If total expenditures continue to grow when there is no economic growth of income, then a contraction will be unavoidable (Tainter 1987). While all the solid materials are to smaller or larger degree recyclable, all energy is in used up and dissipated within a very short timeframe (Sverdrup et al. 2014a,b, 2017). For the type of challenges facing us now, the statistical economic models used so far are not sufficient, and they do not contain required and necessary feedbacks and are unsuitable for policy development (Alexandrova and Northcott 2013; Bossel 1998; Senge et al. 2008; Falk 2017; Hamilton et al. 2015; Moosa 2017; ElSawah et al. 2017; Laniak et al. 2013). 


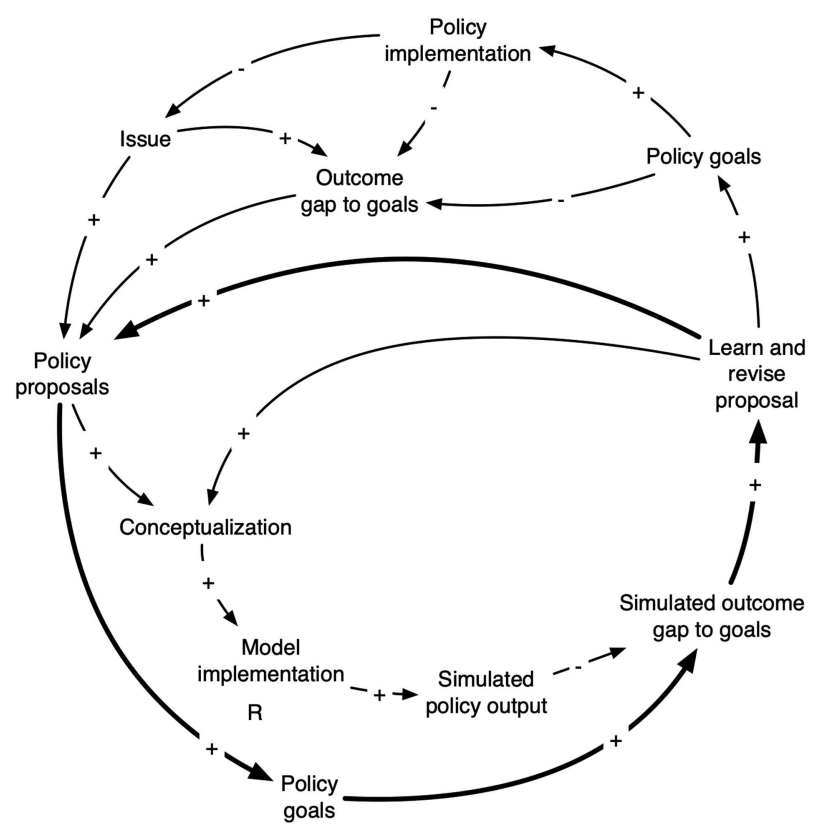

Figure 2.1 The model is used in an iterative mode in responsible performance-based policy development.

\section{Model methodology}

Figure 2.1 shows how the integrated model is used in an iterative mode in policy development. Policy proposals are made, and then the model system is used, either qualitatively or quantitatively, to estimate the effects of that policy if implemented. The outcome is evaluated on how well the goals are achieved if the side-effects are acceptable, and what kind of delays are to be expected. The iterative procedure is kept going until a satisfactory solution can be found or the proposal is rejected as unfeasible. Professional policymaking uses quantitative simulations as support. Then it is important that the models are based in real underlying principles and not just apparent correlations. WORLD7 is energy and mass balance consistent in all aspects, including the economic module. Goal conflicts may show up in the assessments from complex integrated models, so that achieving one policy goal, may actually decrease the possibility of achieving another policy goal. That may lead to hard choices, or an investigation if the system structure can be changed in order to resolve the goal conflict. When the model has been field-tested and found to be able to create the past, based on principles, without fiddling with the model to fit the desired output, then the model becomes an evidence-based assessment tool (Hamilton et al. 2015; ElSawah et al. 2017; Laniak et al. 2013). 


\section{Model description}

WORLD7 operates on a global scale. Thus, there are no countries and no regions. Variables like commodity and resource prices are generated endogenously inside WORLD7 from first principles of supply and demand within the market arbitration mechanism over price. WORLD7 operates in normal mode with a daily time-step but uses yearly printouts of results. The variation in resource quality is taken care of in the ore grade classification. Figure 2.2 shows the basic units of WORLD7. Note that behind every little box in Figure 2.2, there are one or several sub-modules. Every red line is one or more links. In the model, a number of interdependencies are made between different modules and sectors. These links are:

1 Demand linkages

a For some energy production technologies, special materials are needed. They are included in the demand, and purchased in their extraction module and taken to the energy module.

b The extraction of all materials requires energy and this energy is taken from the markets in the energy module.

c Price feedbacks on demand, low price allow for higher demand, high price cause the demand to be lowered.

d Demands in some modules use input from other modules.

2 Supply linkages

a For the dependent materials, secondary extraction is done from mother metals, and the rate depends on the extraction rate of the mother metal.

b When actual supply to a module is less than demand, then the production or activity is reduced.

c When more energy is demanded by resource extraction, than can be supplied, then extraction is reduced.

d Price and supply promote profits, which promotes supply, normally supported by production.

3 Recycling linkages

a Recycling is done for all metals and materials, depending on the price and if there is legislation.

\section{Economy}

a Resource extraction generates income, costs and profit, a basic income in the economic model. The price is generated from supply and demand dynamics (Sverdrup and Olafsdottir 2019). This resource income makes up about half of all value generated. The rest comes from human labour, an invention of technology, technological work enhancement and knowledge input. 


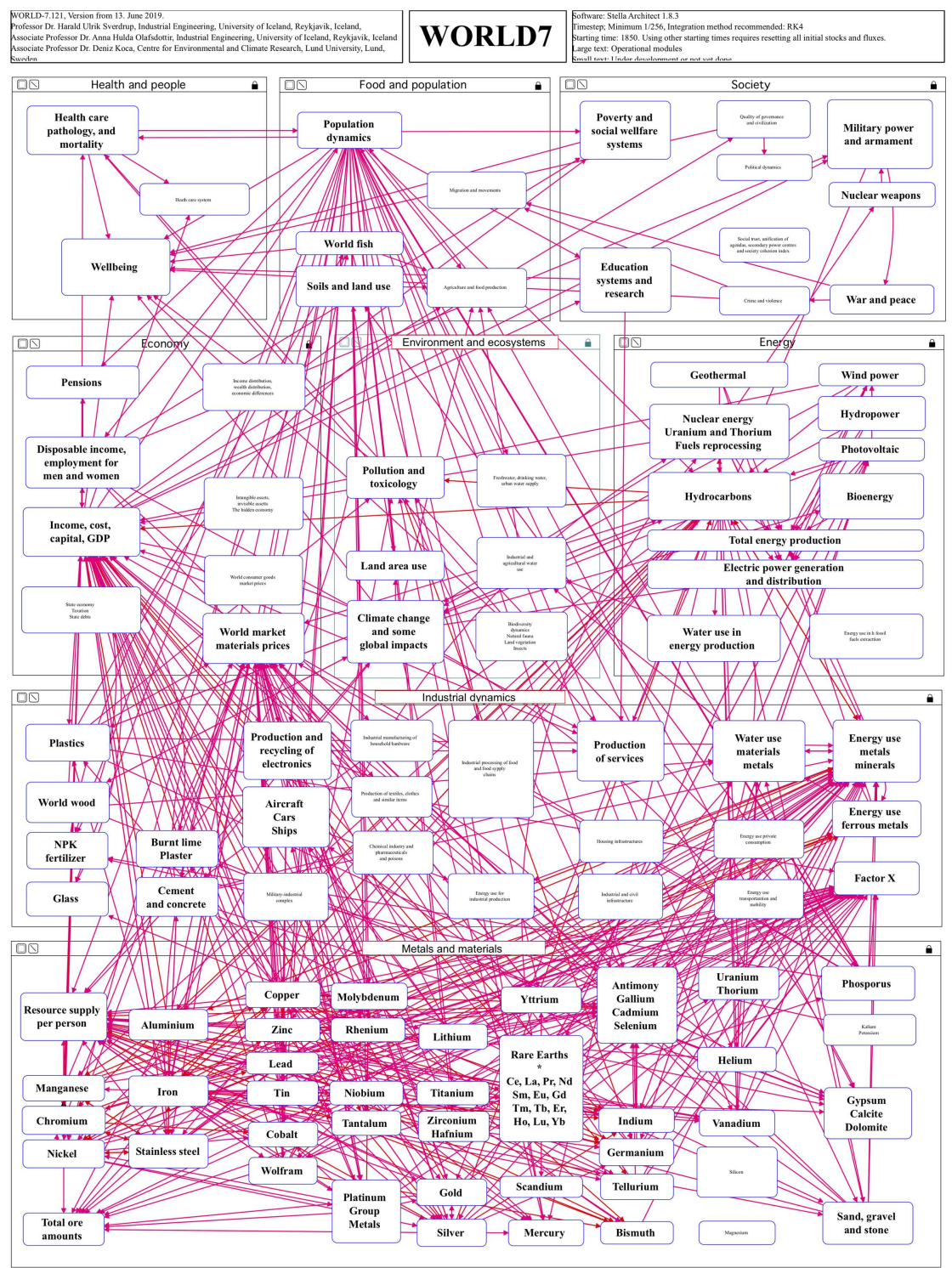

Figure 2.2 Overview of WORLD7 in the STELLA software.

\section{Policy}

a Policy decisions are automated through legislation, and some have significant impacts on many systems being managed. This depends on the institutions of society to be effective and accountable. 


\section{Results}

The WORLD7 model has been tested in several ways to validate how well it performs against observed system state data. The model reproduces observed data really well. The tests were done on the extraction rates, supply rates, recycling, market prices for 40 different the materials and metals for the time 1850-2020 (Sverdrup et al. 2013, 2014a,b, 2015a,b, 2017, 2018a,b; Sverdrup and Ragnarsdottir 2014; Sverdrup and Olafsdottir 2019; Olafsdottir and Sverdrup 2018; Sverdrup 2017). The model reproduces the decline in resource quality for the materials where this can be checked (Gold, silver, copper, nickel, iron, chromium, manganese, oil, phosphorus, uranium) with equally good success. WORLD7 has a simplified climate change model based on a global carbon balance, ecosystems, land-use and use of fossil fuels. It is capable of recreating the climate trends observed for the time from 1850 to 2015 for atmospheric $\mathrm{CO}_{2}$, average global temperature and sea-level rise. WORLD7 is capable of recreating the GDP and the GDP per capita for the period 1850-2018 with good accuracy.

Figure 2.3a shows the supply of lithium in the long term and the supply in $\mathrm{kg}$ per capita per year. Around 2100, lithium goes from soft scarcity to hard scarcity. That occurs when the supply becomes less that the modified demand, indicating that supply cannot meet demand. That implies that there will not be enough lithium to substitute electric vehicles for all fossil fuel vehicles presently in use. The curves for cobalt are similar but more restricting, and cobalt will be a resource that will become scarce. Figure $2.3 \mathrm{~b}$ shows a typical output from the model for some of the strategic technology metals.

These metals are required for a number of new technologies in alternative energy production and high-performance electronics as well as the smaller of electrical motors and engines. In order to substitute fossil energy with solar panel electricity, great care must be taken in order to use the different technologies in parallel. Each individual photovoltaic technology, whether based on gallium, germanium, indium or telluride, will not have the capacity alone. And the panels must be designed in such a way that they can be recycled. Else it will run into hard scarcity and stop.

As more and more energy is required for resource extraction, and an increasing total fraction of GDP must be used for energy and materials extraction and production. The fraction of GDP used for extracting natural resources. It will go from $12 \%$ now to $25 \%$ by 2250 according to the "business-as-usual scenario' (Figure 2.4a). Dramatic changes will be necessary in the attitude to energy use and materials use and recycling will be required to bring demand down. The fraction of all energy used for resource extraction is steadily increasing, reflecting that Benefit Return On Investment sinks as the resource quality decline (BeROI goes down). This fraction of all energy available is steadily increasing, reflecting that BeROI sinks as the resource quality decline (Figure 2.4b). The decline in resource quality is already being observed. 

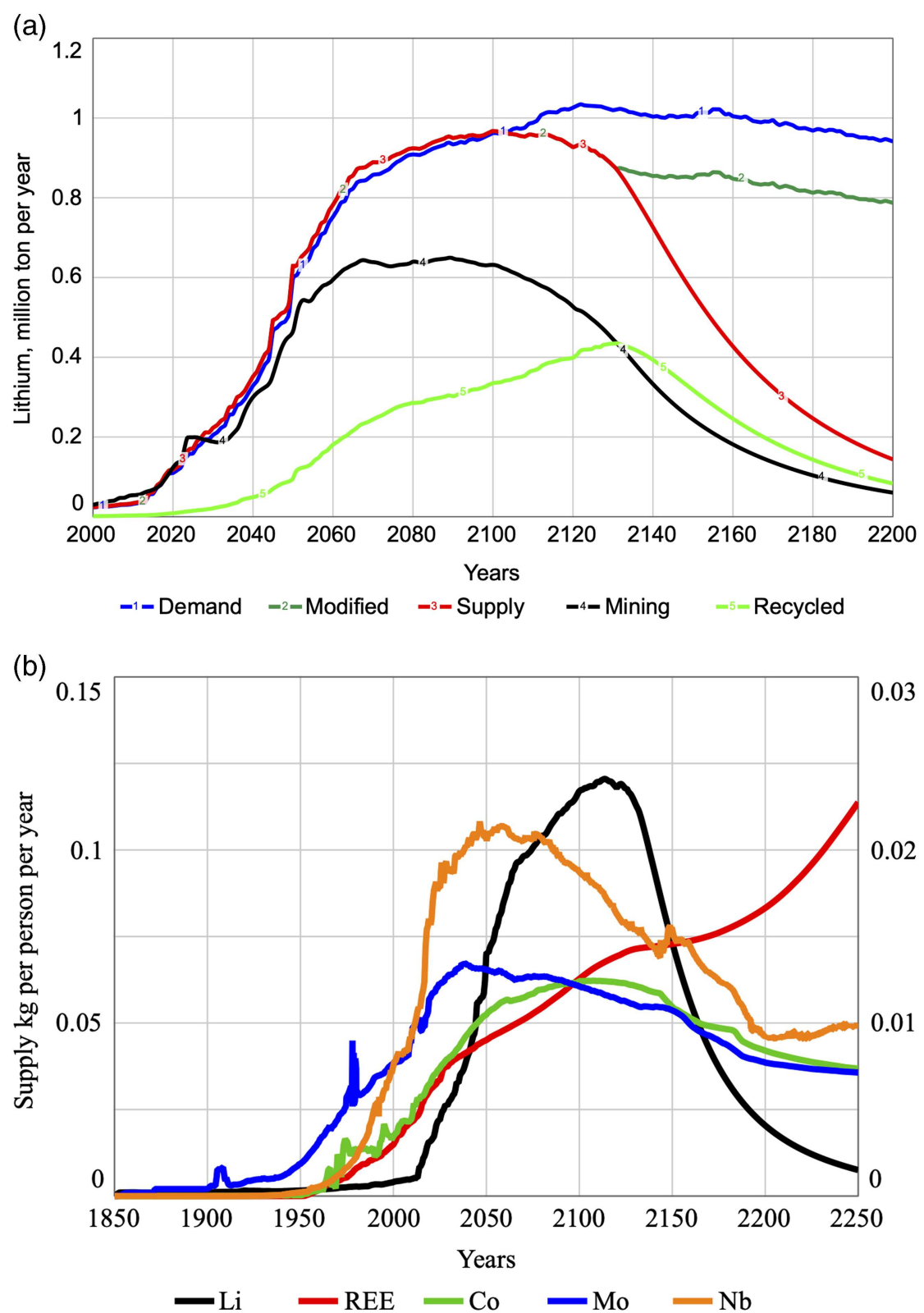

Figure 2.3 (a) The supply and demand of lithium. Around 2100, lithium goes from soft scarcity to hard scarcity. First demand separates from price modified demand. Then supply separates from price-modified demand. Supply cannot meet demand, despite willingness to pay. (b) Supply per person per year for some of the key metals for solar photovoltaic panels. The supply is sensitive to how well recycling can be managed for these elements. 
(a)

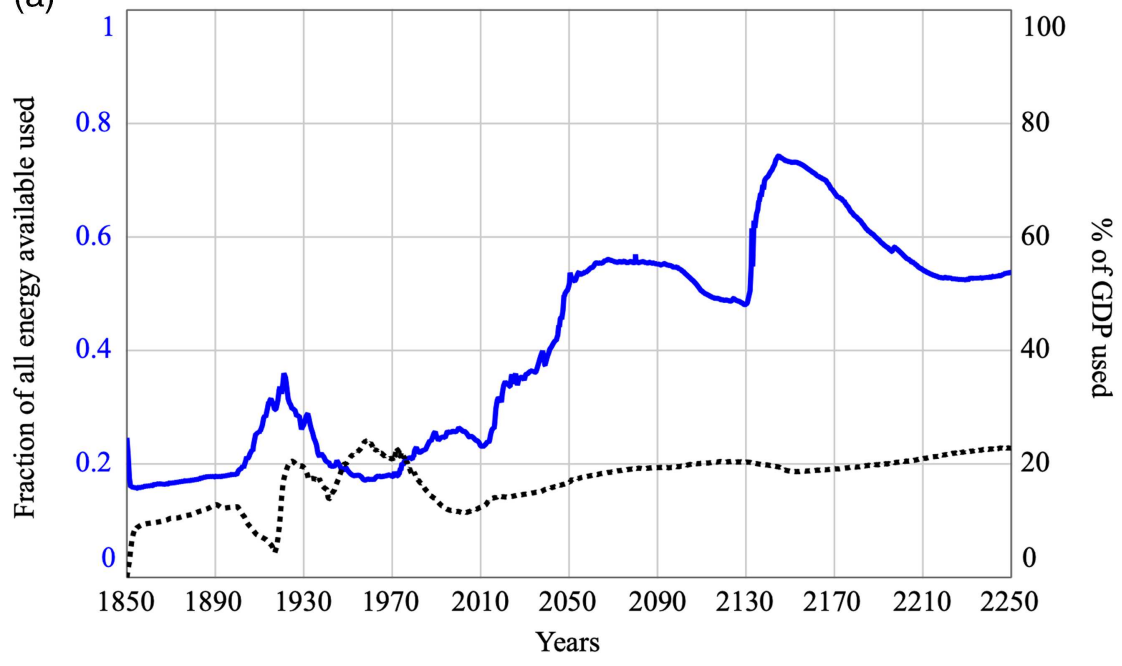

— Fe, Ni, Cr, Mn, Cu, Zn, Pb, Cement, Plastics, Stony materials

.....\% of GDP used for resource production

(b)

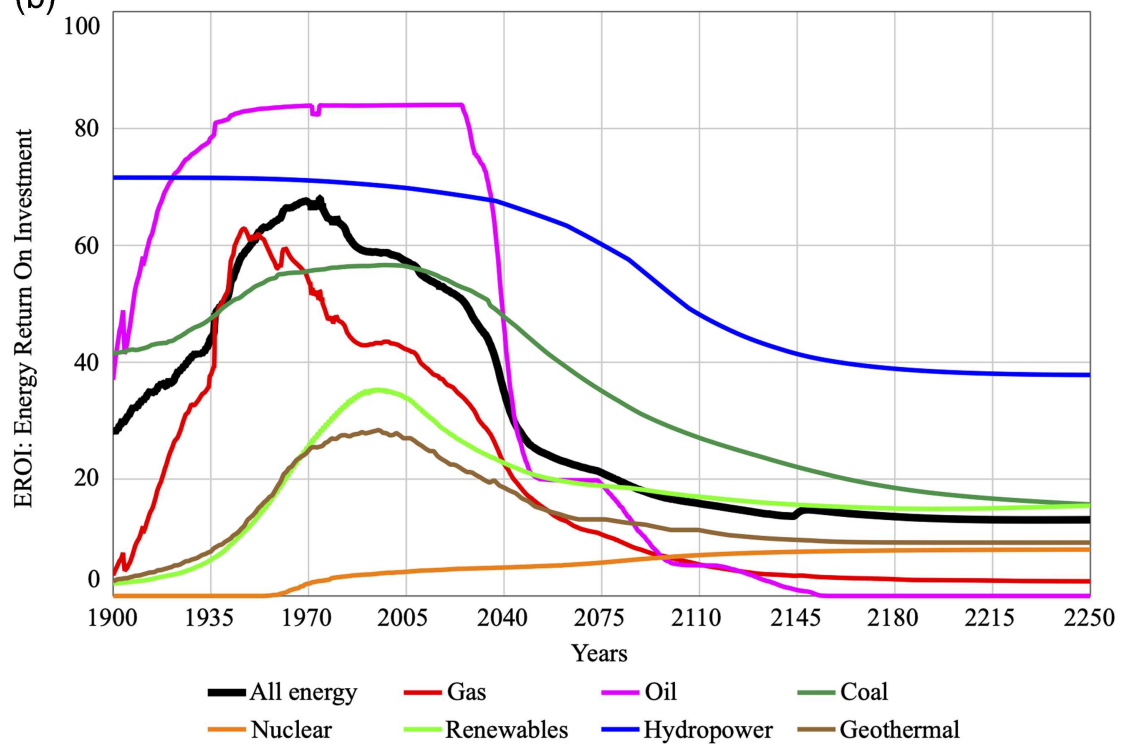

Figure 2.4 (a) Total fraction of all energy demanded by resource extraction. (b) Estimated EROI development under business-as-usual for different energy types. 


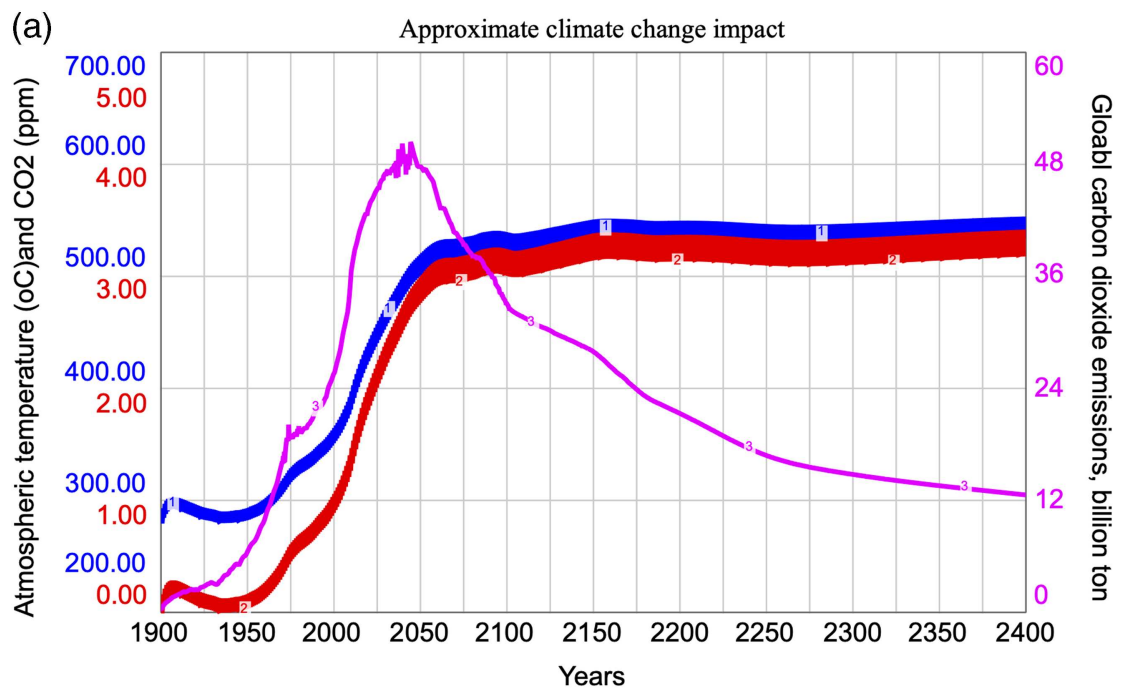

(b) Approximate climate change impact

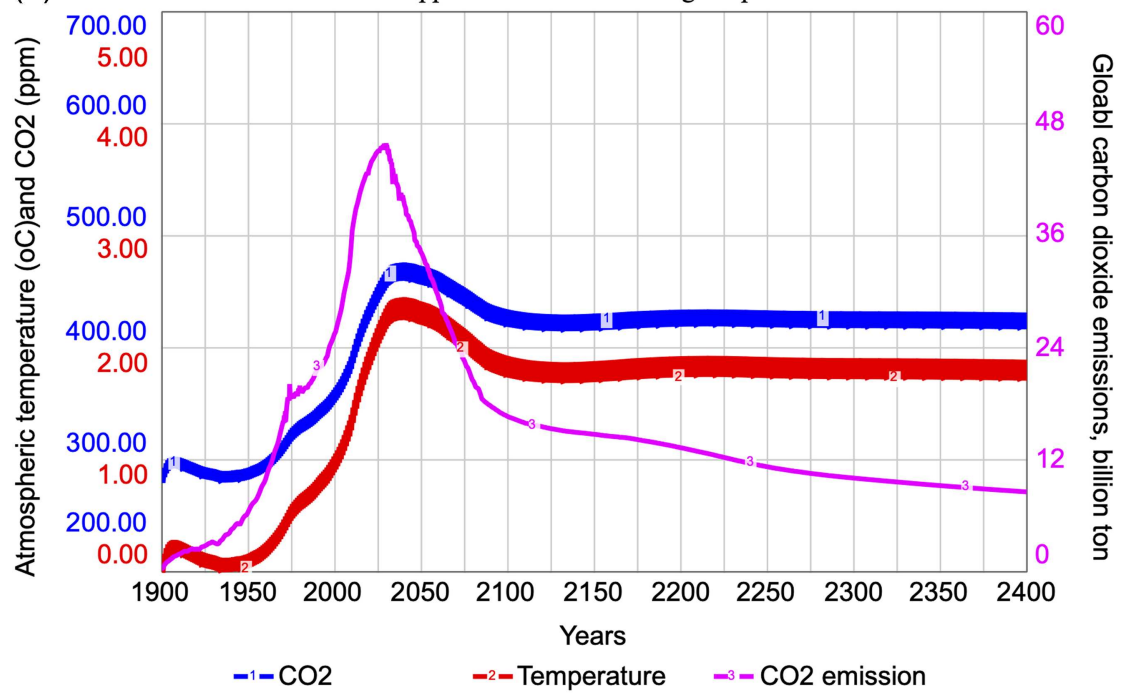

Figure 2.5 Climate change outcomes for (a) the business-as-usual case and (b) the 'Max $2^{\circ} \mathrm{C}$ global warming' scenario, phasing out of $90 \%$ of all fossil fuel use between 2020-2060. 
Figure 2.5 shows examples from some of the assessment made for the German government where different energy scenarios were tested with respect to business-as-usual and the German 'Energiewende' policy (Lorenz et al. 2017). The results for 'business as usual' shows that the long period of growth that has lasted from 1950 to the present will stagnate after 2030. The drivers behind the economic growth are several; the increase in population, matched by unbounded resource extraction and great improvements in work efficiency through technology and industrial organization of work.

The simulation for 'Max $2^{\circ} \mathrm{C}$ global warming' showed that the German 'Energiewende' policy is both possible and profitable in the long run. In order to do so, a 'Ressourcewende' would be necessary, reducing material resource losses and increase recycling. The runs suggest that a 'Energiewende' policy would be applicable on a global scale without any significant long term negative effects to the global economy. The simulation predict a positive effect on GDP development and global employment. The 'Max $2{ }^{\circ} \mathrm{C}$ global warming' goal from Paris could be achieved by phasing out $90 \%$ of all fossil fuels use worldwide (Figure 2.5) 2020-2040. It will take away old jobs in the fossil industry and make old businesses that cannot change become obsolete. It will create more new companies and jobs in the new industries and services that needs to be developed.

\section{Discussion}

All of the scientific weaknesses exploited in the attempts to discredit the results from the World1, World2 and World3 models, have been amended in WORLD7. Major progress with the robustness of the model comes from adding a biophysical economic model to the integrated model. When economic deficits occur, debts and policies can be taken to bridge the gap, preventing the world from crashing. as in the earlier models. WORLD7 is based on causal links from natural resources to economic wealth, and it is capable of simulating periods of economic growth, stagnation, crisis and contraction as they come.

Table 2.1 shows a summary of policies suggested by others (Randers 2012) that we have tested with WORLD7. Many policies have been proposed with the best of intentions, but they do not always work the way it was wanted. The point is that every policy proposal needs to calculated through in order to check that it really produces the desired outcome, as well as does not produce side-effects that are unacceptable.

The problems and challenges faced by the world today are so substantial, covering so many aspects and consistently pervasive on a planetary level, that the mitigations and transformative changes needed are so large. The time window for when humanity could have stopped many of the problems may have already passed, and some damage appears to be unavoidable. But much more damage is to come, and the work must start at once, the time for long debates are long gone. Environmental pollution, climate change and resource 
Table 2.1 A summary of policies suggested by others (see Randers 2012) that we have tested with the WORLD7 model

\begin{tabular}{|c|c|c|c|c|c|}
\hline$\#$ & Policies suggested & Energy & Resources & Social & Works? \\
\hline 1. & $\begin{array}{l}\text { Reduce man-made } \\
\text { greenhouse gas } \\
\text { emissions as soon } \\
\text { as possible - } \\
\text { Global Energie- } \\
\text { wende }\end{array}$ & $\begin{array}{l}\text { Can be done with } \\
\text { better energy } \\
\text { efficiency }\end{array}$ & $\begin{array}{l}\text { Needs a Global } \\
\text { Ressouce- } \\
\text { wende }\end{array}$ & $\begin{array}{l}\text { Depends on being } \\
\text { socially } \\
\text { sustainable. } \\
\text { Limited by } \\
\text { corruption and } \\
\text { poor } \\
\text { governance }\end{array}$ & Yes \\
\hline 2. & $\begin{array}{l}\text { Help poor nations } \\
\text { grow faster - by } \\
\text { rapid } \\
\text { industrialisation } \\
\text { similar to Japan, } \\
\text { Korea and China }\end{array}$ & $\begin{array}{l}\text { Challenging } \\
\text { energy supply, } \\
\text { challenging } \\
\text { pollution risks }\end{array}$ & $\begin{array}{l}\text { High risk for } \\
\text { hard scarcity } \\
\text { on key } \\
\text { technological } \\
\text { materials }\end{array}$ & $\begin{array}{l}\text { Limited by } \\
\text { corruption and } \\
\text { poor } \\
\text { governance }\end{array}$ & Difficult \\
\hline 3. & $\begin{array}{l}\text { Reduce } \\
\text { unemployment } \\
\text { and inequity } \\
\text { through } \\
\text { more jobs }\end{array}$ & $\begin{array}{l}\text { Can be done with } \\
\text { Global } \\
\text { Energie- } \\
\text { wende }\end{array}$ & $\begin{array}{l}\text { Needs a Global } \\
\text { Ressouce- } \\
\text { wende }\end{array}$ & $\begin{array}{l}\text { Social change } \\
\text { stresses. Limited } \\
\text { by corruption } \\
\text { and poor } \\
\text { governance }\end{array}$ & Yes \\
\hline 4 & $\begin{array}{l}\text { Further slow } \\
\text { population } \\
\text { growth - through } \\
\text { positive } \\
\text { incentives }\end{array}$ & $\begin{array}{l}\text { Population } \\
\text { decline reduce } \\
\text { consumption }\end{array}$ & $\begin{array}{l}\text { Population } \\
\text { decline } \\
\text { reduce } \\
\text { consumption }\end{array}$ & $\begin{array}{l}\text { Needs global } \\
\text { attitude change. } \\
\text { Limited by } \\
\text { corruption and } \\
\text { poor } \\
\text { governance }\end{array}$ & Yes \\
\hline 5 & $\begin{array}{l}\text { Do nothing, assume } \\
\text { everything is to } \\
\text { be taken care of } \\
\text { by the markets. } \\
\text { UN high } \\
\text { population } \\
\text { scenario } \\
\text { becomes real }\end{array}$ & $\begin{array}{l}\text { Energie-wende } \\
\text { becomes far } \\
\text { more } \\
\text { challenging to } \\
\text { do. Energy } \\
\text { becomes } \\
\text { expensive }\end{array}$ & $\begin{array}{l}\text { Highest risk that } \\
\text { resource } \\
\text { scarcity strikes }\end{array}$ & $\begin{array}{l}\text { Risk for } \\
\text { dictatorship. } \\
\text { Economic crisis } \\
\text { and stresses } \\
\text { social } \\
\text { disruptions }\end{array}$ & No \\
\hline
\end{tabular}

scarcity will reach out to every corner of the world, and soon the last place to hide will be gone.

- A systemic approach is a condition for resolving the challenges.

- Systemic changes imply that the systemic structure and systemic principles must be changed. Narrow sectorial approaches are neither systemic, nor sufficient, it is not about adjusting the parameters of the present system, feedbacks go across sectors and models that incorporate that are required.

- A circular society for material resources is required. That creates the circular economy. 
- Goal conflicts will demand to be solved at a systemic level.

- $\quad$ Systemic changes need to be multi-sectorial, causally linked and pervasive.

- Energiewende is linked to a Ressourcewende.

- It involves all fundamental systems; industrial, economic and social dynamics. It implies transformative changes to existing society and power-structures.

- Transformative system change takes time.

- Plan with at least 20 years from start to full implementations (Ref; LRTAP protocol, IPCC progress). Starting is needed at once $(2020+20=2040)$.

- Must engage all required arenas to secure a success: Science arena, Communication and Media arena, Political arena.

\section{Conclusions}

WORLD7 has become a powerful tool for making integrated dynamic assessments for the sustainability of nations and the global civilization. The shortcomings or earlier world models have now been overcome. WORLD7 does reconstruct the resource use, industrialization and the economy for the time from 1850 to 2015 with good success. That is a strong argument for taking the forecasts very seriously. In the scenarios for the future, the world does not crash, but many scenarios indicate economic contractions and serious challenges to things we take for granted.

\section{References}

Albin, S. (1997). Building a system dynamics model; Part 1; Conceptualization. MIT System Dynamics Education Project (J. Forrester (Ed)). MIT, Boston. 34pp. https://ocw.mit.edu/ courses/sloan-school-of-management/15-988-system-dynamics-self-study-fall-1998spring-1999/readings/building.pdf.

Alexandrova, A., and Northcott, R. (2013). It's just a feeling: Why economic models do not explain. Journal of Economic Methodology, 20, 262-267. doi:10.1080/1350178X.2013. 828873.

Bardi, U. (2013) Extracted. How the quest for mineral wealth is plundering the planet. The past, present and future of global mineral depletion. A report to the Club of Rome. Vermont: Chelsea Green Publishing 299pp. ISBN 978-1-60358-541-5.

Bossel, H. (1998). Earth at the crossroads. Paths to a sustainable future. Cambridge: Cambridge University Press.

Clark, J., and Cole, S. (1975). Global Simulation Models: A Comparative Study. New York: John Wiley and Sons.

ElSawah, S., Pierce, S. A., Hamilton, S. A., van Delden, H., Haase, D., Elmahdi, A., and Jakeman, A. (2017). An overview of the system dynamics process for integrated modelling of socio-ecological systems: Lessons on good modelling practice from five case studies. 
Environmental Modelling and software 93, 127-145. https://www.sciencedirect.com/ science/article/abs/pii/S136481521631091X?via\%3Dihub.

Forrester, J. W. (1961). Industrial Dynamics. Pegasus Communications. Boston, MA: MIT Press.

Forrester, J. W. (1969). Urban Dynamics. Pegasus Communications. Boston, MA: MIT Press. Forrester, J., (1971). World dynamics. Waltham, MA: Pegasus Communications.

Hamilton, S. H., ElSawah, S., Guillaume, J. H. A., Jake man, A. J., and Pierce, S. A., (2015). Integrated assessment and modelling: Overview and synthesis of salient dimensions. Environmental Modelling and software 64, 215-229.

Haraldsson, H. (2004). Introduction to systems thinking and causal loop diagrams. Reports in Ecology and Environmental Engineering 1, 2004, 5th edition. Lund University, Lund, Sweden.

Haraldsson, H. and Sverdrup, H. (2005). On aspects of systems analysis and dynamics workflow. Proceedings of the systems dynamics society, July 17-21, 2005 International Conference on systems dynamics, Boston, USA. 1-10 pages. http://www.systemdynamics.org/conferences/ 2005/proceed/papers/HARAL310.pdf.

Heinberg, R. (2011). The end of growth. Adapting to our new economic reality. Gabriola Island, Canada: New Society Publishers.

Hoffman, R. (2015). Concepts for a New Generation of Global Modelling Tools: Expanding our Capacity for Perception. Cadmus 2, 134-145.

Keegan, R., and Laskow-Lahey, L. (2014). The real reason people won't change. Harvard Business Review - OnPoint 103-111. Originally published in Harvard Business review November 2001.

Keynes, J. M. (1936). The General Theory of Employment, Interest, and Money. New York: Harcourt Brace.

Keynes, J. M., Salter, A., Stamp, J., Blackett, B., Clay, H., and Beveridge, B. (1932). The World's Economic Crisis and the Way of Escape. Butterworth, London.

Kim, D. H., (1992). Toolbox: Guidelins for Drawing Causal Loop Diagrams. The Systems Thinker, 3, 5-6.

Koca, D. and Sverdrup, H. (2013). Use of Casual Loop Diagramming Methodology and Systems Thinking in Exploring Alternative Climate Change Adaptation Strategies in Seyhan River Basin, Turkey. In; Schwanninger, M., Husemann, E., and Lane, D., Proceedings of the 30th International Conference of the System Dynamics Society, St. Gallen, Switzerland, July 22-26, 2012 Model-based Management. University of St. Gallen, Switzerland; Systems Dynamics Society. 4, 3525-3538. ISBN: 9781622764143 Curran Associates, Inc.

Kotterer, J. P. (2014). Leading change; Why transformations efforts fail. Harvard Business Review - OnPoint 30-37. Originally published in Harvard Business review April 1995.

Laniak, G. F., Olchin, G, Goodall, J., Voinov, A., Hill, M., Glynn, P., Whelan, G., Geller, G., Quinn, N., Blind, M., Peckham, P., Reaney, S., Gaber, N., Kennedy, R., and Hughes, A. (2013). Integrated environmental modeling: A vision and roadmap for the future. Environmental Modelling and software 39, 2-23.

Lorenz, U., Sverdrup, H. U., and Ragnarsdottir, K. V., (2017). Global megatrends and resource use - A systemic reflection. Chapter 3. In: Lehman, H. (Ed). The Factor X book. 67-77. Frankfurt: Springer Verlag.

Meadows, D. H., Meadows, D. L., Randers, J., and Behrens, W. (1972). Limits to growth. New York: Universe Books.

Meadows, D. L., and Meadows, D. H., Eds. (1973). Business and Economics. Geneva, Switzerland. 
Meadows, D. L., Behrens III, W. W., Meadows, D. H., Naill, R. F., Randers, J., and Zahn, E. K. O. (1974). Dynamics of Growth in a Finite World. Massachusetts: Wright-Allen Press, Inc. Meadows, D. H., Meadows, D. L., and Randers, J. (1992). Beyond the limits: Confronting global collapse, envisioning a sustainable future. Vermont, USA: Chelsea Green Publishing Company.

Meadows, D. H., Randers, J., and Meadows, D. (2005). Limits to growth. The 30 year update. New York: Universe Press.

Monbiot, G. (2015). Consume more, conserve more: sorry, but we just can't do both. The Guardian, Tuesday 24 November 2015 19.28 GMT. http://www.monbiot.com/, https:// www.theguardian.com/commentisfree/2015/nov/24/consume-conserve-economic-growthsustainability.

Moosa, I. A. (2017). Econometrics as a Con Art: Exposing the Limitations and Abuses of Econometrics 296pp, Cheltenham: Edward Elgar Publishing Ltd. ISBN-13: 978-1785369940.

Olafsdottir, A. H., and Sverdrup, H. (2018). Modelling global mining, secondary extraction, supply, stocks-in-society, recycling, market price and resources, using the WORLD6 model; Tin. Biophysical Economics and Resource Quality 4, 1-32.

Randers, J. (2012). 2052, a global forecast for the next 40 years. A report to the Club of Rome. Vermont, USA: Chelsea Green Publishing.

Roberts, N., Andersen, D. F., Deal, R. M., and Shaffer, W. A. (1982). Introduction to Computer Simulation: A System Dynamics Approach. Chicago: Productivity Press.

Rockström, J., Steffen, W., Noone, K., Persson, A., Chapin, III F. S., Lambin, E., Lenton, T. M., Scheffer, M., Folke, C., Schellnhuber, H., Nykvist, B., de Wit, C. A., Hughes, T., van der Leeuw, S., Rodhe, H., Sörlin, S., Snyder, P. K., Costanza, R., Svedin, U., Falkenmark, M., Karlberg, M., Corell, R. W., Fabry, V. J., Hansen, J., Walker, B. H., Liverman, D., Richardson, K., Crutzen, C., and Foley, J. (2009). A safe operating space for humanity. Nature 461, 472-475.

Rockström, J., Gaffney, O., Rogelj, J. Meinhausen, M., Nakicenovic, N., and Schellnhuber, H. J. (2017). A roadmap for rapid decarbonization. Science 355 Issue 6331.

Senge, P. (1990). The Fifth Discipline. The Art and Practice of the Learning Organisation. New York: Century Business.

Senge, P. M., Smith, B., Schley, S., Laur, J., and Kruschwitz, N. (2008). The Necessary Revolution: How Individuals and Organisations Are Working Together to Create a Sustainable World. Doubleday Currency, London.

Sterman, J. D. (2000). Business Dynamics, System Thinking and Modelling for a Complex World. New York: Irwin McGraw-Hill.

Sverdrup, H. (2017). Modelling global extraction, supply, price and depletion of the extractable geological resources with the LITHIUM model. Resources, Conservation and Recycling 114, 112-129.

Sverdrup, H. U. (2019). The global sustainability challenges in the future: the energy and materials supply, pollution, climate change and inequality nexus. In: Holden, E., Meadowcraft, J. Langhelle, O., Banister, D., Linnerud, K., (Eds), Our Common Future, What Next for Sustainable Development? 30 years after the Brundtland report. Chapter 1, 7-27, Frankfurt: Springer Verlag.

Sverdrup, H., and Olafsdottir, A. H. (2019). System dynamics modelling of supply, recycling, stocks-in-use and market price for stainless steel using WORLD6. Biophysical Economics and Resource Quality. https://doi.org/10.1007/s41247-019-0056-9.

Sverdrup, H., and Ragnarsdottir, K. V. (2014). Challenging the planetary boundaries II: Assessing the sustainable global population and phosphate supply, using a systems dynamics 
assessment model. Applied Geochemistry 2011; 26, S311-S313, doi:10.1016/j.apgeochem. 2011.03.088.

Sverdrup, H., Koca, D., and Granath C. (2013). Modeling the gold market, explaining the past and assessing the physical and economical sustainability of future scenarios. In; Schwanninger, M., Husemann, E., Lane, D., Proceedings of the 30th International Conference of the System Dynamics Society, St. Gallen, Switzerland, July 22-26, 2012. Model-based Management. University of St. Gallen, Switzerland: Systems Dynamics Society. Pages 5: 4002-4023. ISBN: 9781622764143 Curran Associates, Inc.

Sverdrup, H., Koca, D., and Ragnarsdottir, K. V. (2014a). Investigating the sustainability of the global silver supply, reserves, stocks in society and market price using different approaches. Resources, Conservation and Recycling 83, 121-140.

Sverdrup, H. and Ragnarsdottir, K. V. (2014b). Natural Resources in a planetary perspective. Geochemical Perspectives 2: 129-341. European Geochemical Society. http://www. geochemicalperspectives.org/online/v3n2.

Sverdrup, H., Koca, D., and Ragnarsdottir, K. V. (2015a). Aluminium for the future: Modelling the global production, assessing long term supply to society and extraction of the global bauxite reserves. Resources, Conservation and Recycling 103, 139-154.

Sverdrup, H., and Ragnarsdottir, K. V. (2015b). The future of platinum group metal supply; An integrated dynamic modelling for platinum group metal supply, reserves, stocks-inuse, market price and sustainability. Resources, Conservation and Recycling 114, 130-152.

Sverdrup, H. U., Ragnarsdottir, K. V., and Koca, D. (2017). An assessment of global metal supply sustainability: Global recoverable reserves, mining rates, stocks-in-use, recycling rates, reserve sizes and time to production peak leading to subsequent metal scarcity. Journal of Cleaner Production 140, 359-372, doi:10.1016/j.jclepro.2015.06.085.

Sverdrup, H., Olofsdottir, A. H., Ragnarsdottir, K. V., and Koca, D. (2018a). A system dynamics assessment of the supply of molybdenum and rhenium used for superalloys and specialty steels, using the WORLD6 model. Biophysical Economics and Resource Quality 4, 1-52.

Sverdrup, H., Olafsdottir, A. H., Ragnarsdottir, K.V., Koca, D., and Lorenz, U. (2018b). The WORLD6 integrated system dynamics model: Examples of results from simulations. Proceedings from the 2018 World Resources Forum, Geneva, Switzerland. 11 pages. Matasci, C. (Ed) 'Accelerating the Resource Revolution', highlighting the importance of the Sustainable Development Goals and the Paris Climate Agreement as calls for action. World Resources Forum 2018, St. Gallen, Switzerland. https://www.wrforum.org/.

Sverdrup, H., Olafsdottir, A. H., and Ragnarsdottir, K. V. (2019). Development of a biophysical economics module for the global integrated assessment WORLD6 model. In: Cavana, R., Pavlov, O., Dangerfield, B., Wheat, D. (Eds), Modelling Feedback Economics. 47 pages. Frankfurt: Springer Verlag.

Tainter, J. A. (1987). The Collapse of Complex Societies. Cambridge: Cambridge University Press. 250pp.

Voinov, A. A. (2010). Systems science and modelling for ecological economics. London, UK: Academic Press. 